\title{
SHARIA COMPLIANCE, SHARIA GOVERNANCE, DAN ENVIROMENTAL ACCOUNTING SEBAGAI PERTANGGUNGJAWABAN LEMBAGA AMIL ZAKAT DI INDONESIA
}

\author{
Fika Azmi $^{1)}$, Ardian Widiarto ${ }^{2)}$, Nugroho Heri Pramono ${ }^{3)}$ \\ Sekolah Tinggi Ilmu Ekonomi Bank BPD Jateng \\ Email :fixs2002@gmail.com
}

\begin{abstract}
This study aims to determine the effect of attitudes and beliefs accountants and managers of interest in disclosing sharia compliance, sharia governance, and enviromental accounting. The sample used in this study is 30 data observation of accountans and managers of amil zakat institutions in Indonesia. Technique the sampling used is using simple random sampling. The result of the study show that simultaneosly the attitude and trust accountants and manager influence interest expressing sharia compliance, sharia governance, and enviromental accounting. Whereas on the other hand partial attitudes and beliefs do not affect the interests off accountants and managers in expressing sharia compliance, sharia governance, and enviromental accounting.
\end{abstract}

Keywords : sharia compliance, sharia governance, enviromental accounting.

\begin{abstract}
Abstrak
Riset tersebut bertujuan untuk mengetahui pengaruh sikap dan kepercayaan akuntan serta manajer terhadap minat dalam mengungkapkan sharia compliance, sharia governance, dan enviromental accounting. Riset tersebut menggunakan sampel 30 data pengamatan pada akuntan dan manajer lembaga amil zakat yang terdapat di Indonesia. Selain itu, riset tersebut menggunakan simple random sampling untuk pengambilan sampelnya. Hasil riset membuktikan bahwa secara simultan variabel sikap dan kepercayaan akuntan serta manajer berpengaruh terhadap minat dalam mengungkapkan sharia compliance, sharia governance, dan enviromental accounting. Sedangkan secara parsial sikap dan kepercayaan tidak berpengaruh terhadap minat akuntan serta manajer dalam mengungkapkan sharia compliance, sharia governance, dan enviromental accounting.
\end{abstract}

Kata Kunci : sharia compliance, sharia governance, enviromental accounting. 
Vol.2, No. 2, Mei. 2019

\section{PENDAHULUAN}

Sharia compliance dan sharia governance saat ini menjadi topik yang banyak diteliti sebagai pengungkapan kepatuhan dan pertanggungjawaban bank syariah terhadap prinsip-prinsip syariah. Pernyataan tersebut selaras dengan aturan yang dibuat oleh AAOIFI tahun 2003 yang mewajibkan bank syariah menyediakan informasi kepatuhan terhadap prinsip syariah. Namun demikian, tanpa adanya aturan yang diwajibkan oleh AAOIFI tersebut, sebagai bank Islam, manajemen bank syariah hendaknya melakukan kegiatan operasional bank syariah dengan berlandaskan prinsip-prinsip syariah yang bersumber dari Alquran dan Hadist. Berdasarkan aturan yang dibuat oleh AAOIFI, Hameed et al. (2003) menganjurkan Index Pengungkapan Islam (IDI) guna pemenuhan informasi ketaatan bank syariah terhadap prinsip syariah. IDI dibangun berdasarkan 3 indikator pengungkapan islami, yaitu: sharia compliance, corporate governance, dan enviromental disclousure.

Riset selanjutnya, Hameed \& Rizal (2003), menekankan bahwa dari tiga komponen IDI yang sesuai sebagai pertanggungjawaban penyediaan informasi kepatuhan syariah adalah pengungkapan sharia compliance. Selain itu, riset Asrori tahun 2011 dengan dasar teori tindakan beralasan, memperoleh keyakinan bahwa sikap dan keyakinan dapat memengaruhi minat manajer dan akuntan bank syariah dalam mengungkapkan sharia compliance.

Hamza (2013), di dalam risetnya yang dilakukan di Malaysia, mengemukakan bahwa sharia governance yang diterapkan terpusat di Malaysia merupakan model pengawasan yang efektif sebagai pertanggungjawaban bank syariah dalam memenuhi kewajiban menyediakan informasi kepatuhan syariah. Riset lain, Hasan (2011), mengemukakan sharia governance penting untuk diterapkan pada bank syariah di Malaysia, GCG Contries, dan Inggris sebagai pertanggungjawaban bank syariah dalam memenuhi penyediaan informasi kepatuhan terhadap prinsip syariah.

Indikator lain yang penting untuk diteliti dalam menjelaskan pertanggungjawaban bank syariah terhadap prinsip syariah selain sharia compliance dan sharia governance adalah enviromental accounting. Enviromental accounting merupakan satu kesatuan demgan social disclosure yang harus diungkapkan sebagai pertanggungjawaban bank syariah terhadap prinsip syariah. Selain fungsinya sebagai pertanggungjawaban kepada Allah SWT (habluminallah) yakni kepedulian bank syariah terhadap lingkungan, enviromental accounting juga berfungsi sebagai pertanggungjawaban bank syariah kepada seluruh pemegang kepentingan (habluminannas). Maali, Peter and Christoper (2006), melakukan riset eksplorasi dengan membuat model yang tepat untuk pengungkapan sosial bank syariah. Riset tersebut bertujuan untuk menilai sejauh mana bank syariah memiliki kesadaran untuk melakukan pengungkapan sosial yang berguna bagi para pemegang kepentingan.

Riset-riset yang telah dilakukan sebelumnya, hampir sama dilakukan pada bank syariah. Padahal, perlu diketahui bahwa lembaga amil zakat (LAZ) juga merupakan suatu unit usaha syariah yang perlu adanya pengawasan dalam kegiatan operasionalnya, baik dari pengawasan dalam melakukan penghimpunan 
dana dari orang yang memiliki kelebihan harta (muzzaki), maupun pengawasan dalam melakukan penyaluran dana kepada orang yang kekurangan harta (mstahik). Selain dilakukannya pengawasan, LAZ yang notabene berpedoman pada Alquran dan Hadist juga memiliki kewajiban untuk melakukan pengungkapan kepatuhan syariah dan pengungkapan tata kelola perusahaan yang baik serta pengungkapan lingkungan sebagai pertanggungjawaban LAZ terhadap prinsip syariah.

Satu hal terpenting mengapa LAZ harus melakukan pengungkapan kepatuhan syariah, pengungkapan sosial, dan tata kelola perusahaan yang baik adalah bahwa suatu bisnis syariah harus dibangun berdasarkan prinsip sharia enterprise theory yang menekankan pada nilai keadilan terhadap manusia dan lingkungan (Triyuwono, 2006). Namun demikian, manusia yang bekerja dalam suatu perusahaan terkadang melakukan kesalahan yang dapat menimbulkan kerugian untuk dirinya dan orang lain. Oleh karena itu, sikap dan kepercayaan yang dapat memengaruhi minat manajemen LAZ dalam mengungkapkan IDI perlu diteliti lebih lanjut. Tujuan riset tersebut adalah mengetahui pengaruh sikap dan kepercayaan akuntan dan manajer LAZ terhadap minat mengungkapkan sharia complaince, sharia governance, dan enviromental accounting. Adapun kontribusi riset tersebut antara lain: memberikan kontribusi positif dalam literatur akuntansi syariah, terutama dalam kajian tentang sharia compliance, sharia governance, dan enviromental accounting. Riset tesebut juga dapat dijadikan sebagai motivasi untuk meningkatkan pertanggungjawaban LAZ dalam menyediakan informasi kepatuhan pada prinsip syariah. Selain itu juga, riset tersebut dapat dijadikan dasar pengambilan keputusan muzzaki dalam menyalurkan hartanya kepada LAZ serta riset tersebut dapat dijadikan motivasi untuk memberlakukan fungsi evaluasi pelaksanaan kepatuhan syariah di bisnis syariah.

\section{KERANGKA TEORITIS DAN PENGEMBANGAN HIPOTESIS}

\subsection{Sharia Enterprise Theory}

Berdasarkan pandangan sharia enterprise theory, penyaluran harta tidak hanya berlaku bagi yang memodali bisnis perusahaan, melainkan pihak lain yang tidak memodali perusahaan (Triyuwono, 2006). Berdasarkan hal tersebut maka, perusahaan yang dijalankan dengan dasar sharia enterprise theory idealnya dapat memberikan kemaslahatan bagi makhluk ciptaan Allah SWT.

\subsection{Teori Tindakan Beralasan}

Ajzen dan Fishbein (1980) menyatakan bahwa teori tindakan beralasan yaitu sikap memengaruhi tingkah laku dalam pembuatan keputusan yang teliti dan beralasan. Dampak dari hal tersebut antara lain: Pertama, tingkah laku lebih banyak ditentukan oleh sikap yang spesifik terhadap sesuatu. Kedua, tingkah laku juga dipengaruhi oleh norma-norma subjektif. Ketiga, sikap dan norma-norma subjektif membentuk minat untuk berperilaku. 
Vol.2, No. 2, Mei. 2019

\subsection{Sharia Compliance, Sharia Governance, and Enviromental Accounting}

Hameed et al. (2003) mengemukakan bahwa sharia compliance adalah suatu alat yang digunakan untuk menilai pertanggungjawaban dalam menyediakan informasi ketaatan bank syariah terhadap prinsip syariah. Bangunan terpenting dalam pengembangan lembaga keuangan syariah adalah ketaatan syariah. Bangunan tersebut menjadikan pembanding mendasar perusahaan syariah dengan konvensional. Guna meyakinkan dapat dijalankannya prinsip syariah pada bisnis syariah, diperlukan kontrol oleh DPS.

Selain sharia compliance, indikator pengungkapan syariah yang penting adalah sharia governance dan enviromental accounting. Hameed et al. (2003) menjelaskan bahwa sharia governance adalah suatu pengaturan perusahaan yang benar sesuai Alquran dan Hadist. Dalam hal tersebut, LAZ harus mampu menerapkan pengaturan LAZ yang benar sesuai Alquran dan Hadist. Sharia governance berbeda dengan good corporate governance. Perbedaan yang mendasar adalah pada sharia governance harus memiliki dewan komisaris dan dewan pengawas syariah sebagai alat pengendalian perusahaan agar bertanggungjawab memenuhi kewajiban penyediaan informasi kepatuhan terhadap prinsip syariah. Sedangkan good corporate governance hanya memerlukan dewan komisaris saja.

Disamping itu, Hameed et al. (2003) juga menjelaskan enviromental accounting adalah pertanggungjawaban terhadap lingkungan yang meliputi: laporan penghematan energi, hubungan dengan komunitas, pelaporan masalah karyawan, dan kepatuhan terhadap ijin dan regulasi pemerintah. Tujuan perusahaan atau organsisasi melakukan pengungkapan enviromental accounting adalah bentuk pertanggungjawaban kepada Allah SWT dan pertanggungjawaban kepada manusia dan lingkungan alam.

\subsection{Kerangka Pemikiran Teoritis}

LAZ merupakan suatu usaha syariah yang notabene dasar pendiriannya berdasrkan prinsip syariah yang bersumber dari Alquran dan Hadist. Sehingga baik kegiatan operasionalnya maupun pembuatan produk-produknya harus berdasarkan prinsip syariah pula. Oleh karena itu, LAZ wajib mengungkapkan sharia compliance, sharia governance, dan enviromental accounting. Hal ini juga sesuai dengan sharia enterprise theory bahwa manusia maupun organisasi merupakan Khalifatullah fiil Ardh. Artinya, dalam melakukan kegiatan di muka bumi harus amanah. Baik amanah kepada Allah SWT maupun amanah kepada makhluk ciptaan Allah lainnya.

Oleh karena itu, minat LAZ mau mengungkapkan sharia compliance, sharia governance, dan enviromental accounting sebagai alat pertanggungjawaban dalam memenuhi kewajiban penyediaan informasi kepatuhan terhadap prinsip syariah perlu dianalisis lebih lanjut. Banyaknya riset terdahulu yang meneliti pengungkapan kepatuhan bank syariah dan masih sedikitnya riset pengungkapan syariah pada LAZ, maka riset tersebut bermaksud menjelaskan dan menganalisis pengungkapan syariah pada LAZ. Hal ini dilakukan karena, dalam melaksanakan kegiatan operasionalnya, LAZ perlu diawasi dalam membuat produk maupun 
dalam mengelola dana muzzaki yang hendak disalurkan kepada mustahik. Berdasarkan sharia enterprise theory dan riset terdahulu, berikut adalah kerangka riset yang dapat disajikan:

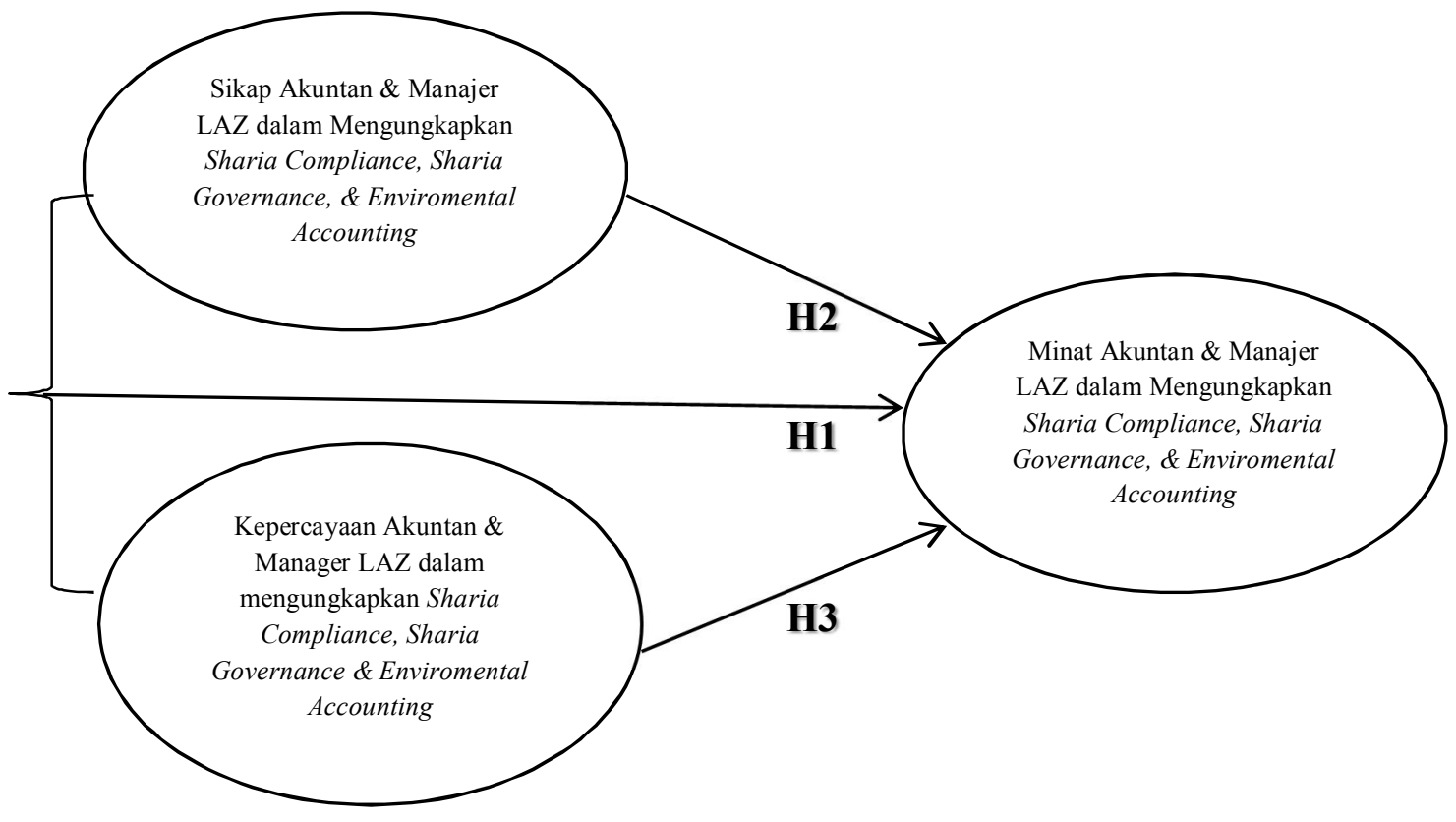

Gambar 2.1 Kerangka Pemikiran Teoritis

\section{METODE RISET}

\subsection{Desain Riset}

Riset ini menggunakan pendekatan kuantitatif, data yang digunakan dapat diukur dengan skala numerik (Kuncoro, 2009). Semua data yang digunakan yakni sikap, keyakinan, dan minat akuntan dan manajer diukur menggunakan skala interval.

\subsection{Populasi, Sampel, dan Teknik Pemilihan Sampel}

Populasi dari riset ini adalah LAZ yang ada di Indonesia. Sedangkan sampel dari riset ini adalah seluruh populasi riset. Teknik pemilihan sampel yang digunakan adalah metode survey, dimana semua populasi digunakan untuk sampel riset.

\subsection{Variabel Riset dan Definisi Operasional Variabel}

\subsubsection{Variabel Dependen}


Variabel dependen dari riset ini adalah minat akuntan dan manajer LAZ dalam mengungkapkan sharia compliance, sharia governance, dan enviromental accounting.

\subsubsection{Variabel Independen}

Variabel independen dari riset ini yakni: sikap dan kepercayaan akuntan dan manajer LAZ dalam mengungkapkan sharia compliance, sharia governance, dan enviromental accounting yang diukur menggunakan skala interval.

\subsubsection{Definisi Operasional Variabel}

Definisi operasional variabel yang pertama adalah sikap terhadap praktik pengungkapan sharia compliance, sharia governance, dan enviromental accounting yakni suatu evaluasi kepercayaan atau perasaan positif dan negatif individu akuntan dan manajer LAZ terhadap praktik pengungkapan sharia compliance, sharia governance, dan enviromental accounting sebagai pertanggungjawaban Islami memenuhi penyediaan informasi kepatuhan LAZ terhadap prinsip syariah. Variabel ini diukur berdasarkan perasaan individu akuntan dan manajer LAZ terhadap 16 item pengungkapan sharia compliance, sharia governance, dan enviromental accounting sebagai instrumen pertanggungjawaban penyediaan informasi kepatuhan LAZ terhadap prinsip syariah. Pengukuran variabel sikap digunakan skala interval dengan lima rentang yakni: sangat berguna $(S B=5)$, berguna $(B=4)$, cukup berguna $(C B=3)$, kurang berguna $(\mathrm{KB}=2)$, dan tidak berguna $(\mathrm{TB}=1)$.

Kedua, kepercayaan terhadap pengungkapan sharia compliance, sharia governance, dan enviromental accounting yakni persepsi atau pandangan akuntan dan manajer LAZ terhadap 16 item pengungkapan sharia compliance, sharia governance, dan enviromental accounting. Pengukuran setiap item pengungkapan digunakan skala interval, dengan lima rentang sangat percaya $(\mathrm{SP}=5)$, percaya $(\mathrm{P}=4)$, cukup percaya $(\mathrm{CP})$, kurang percaya $(\mathrm{KP}=2)$, dan tidak percaya $(\mathrm{TP}=1)$.

Ketiga, minat mengungkapkan sharia compliance, sharia governance, dan enviromental accounting adalah keinginan atau kehendak individu akuntan dan manajer LAZ sebagai pertanggungjawaban penyediaan informasi kepatuhan LAZ terhadap prinsip syariah. Variabel ini diukur berdasarkan keinginan individu akuntan dan manajer LAZ terhadap 16 item pengungkapan syariah. Pengukuran digunakan skala interval dengan lima rentang sangat minat $(\mathrm{SM}=5)$, minat $(\mathrm{M}=4)$, cukup minat $(\mathrm{CM}=3)$, kurang minat $(\mathrm{KM}=2)$, dan tidak minat $(\mathrm{TM}=1)$.

\subsection{Prosedur Pengumpulan Data}

Prosedur pemungutan data riset tersebut dengan membagikan kuesioner kepada LAZ yang ada di Indonesia. Data yang dikumpulkan berupa data primer 
yaitu mengenai sikap, keyakinan, dan minat akuntan dan manajer LAZ yang ada di Indonesia dalam melakukan pengungkapan sharia compliance, sharia governance, dan enviromental accounting.

\subsection{Teknik Analisa Data}

\subsubsection{Analisa Statistik Deskriptif}

Analisis statistik deskriptif dalam riset tersebut adalah distribusi frekuensi. Distribusi frekuensi merupakan dasar bagi statistik deskriptif dan menjadi prasarat untuk menggambarkan seperangkat data (Sarwono, 2012).

\subsubsection{Uji Hipotesis}

Pengujian hipotesis dalam riset tersebut menggunakan analisis regresi berganda dengan alat bantu SPSS. Analisis regresi berganda digunakan untuk menguji pengaruh sikap dan keyakinan akuntan dan manajer LAZ terhadap minat mengungkapkan sharia compliance, sharia governance, dan enviromental accounting. Persamaan regresi dapat dituliskan sebagai berikut:

$$
\mathbf{Y}=\boldsymbol{\alpha}+\mathbf{B I X I}+\mathbf{B 2 X} \mathbf{2}+\mathbf{e}
$$

Keterangan:

$\mathrm{Y}=$ Minat akuntan dan manajer dalam mengungkapkan sharia compliance, sharia governance, dan enviromental accounting.

$\alpha=$ konstanta

$\mathrm{BI}$ s/d B2 = koefisien regresi masing-masing variabel independen.

$\mathrm{XI}=$ Sikap akuntan dan manajer dalam mengungkapkan sharia compliance, sharia governance, dan enviromental accounting.

$\mathrm{X} 2$ = Kepercayaan akuntan dan manajer dalam mengungkapkan sharia compliance, sharia governance, dan enviromental accounting.

$\mathrm{e}=$ error

\subsubsection{Koefisien Determinasi}

Ghozali (2015) menerangkan koefisien determinasi merupakan pengukuran untuk menghitung kemampuan model dalam menjelaskan variasi variabel dependen. Nilai koefisien determinasi 0 sampai dengan 1.

\subsubsection{Uji Simultan (Uji F)}

Ghazali (2015) memaparkan uji simultan adalah pengujian terhadap signifikansi model secara bersamaan variabel independen terhadap variabel dependen. Uji simultan dilakukan dengan membandingkan tingkat kesalahan $\alpha=$ $5 \%$ dengan nilai signifikansi. 


\subsubsection{Uji Parsial (Uji t)}

Ghazali (2015) memaparkan uji parsial adalah uji untuk menentukan apakah variabel independen secara individu berpengaruh terhadap variabel dependen. Uji parsial digunakan dengan membandingkan tingkat kesalahan $\alpha=5 \%$ dengan nilai signifikansi.

\section{ANALISIS DATA DAN PEMBAHASAN}

\subsection{Analisis Deskriptif Profil Responden}

Berdasarkan hasil uji statistik frekuensi, komposisi usia responden riset tersebut menunjukkan bahwa usia responden merata dari usia 24 sampai dengan usia 40 tahun. Hal ini artinya usia responden adalah pada masa usia produktif untuk bekerja.

Berdasarkan hasil uji statistik frekuensi, tingkat pendidikan responden sebagian besar adalah strata 1 yakni sebesar $73,3 \%$. Hal ini menunjukkan bahwa responden sadar tentang pentingnya pendidikan dan memiliki kemampuan untuk bekerja secara profesional.

Berdasarkan hasil uji statistik frekuensi, sebagian besar responden memiliki lama bekerja 1 sampai dengan 2 tahun yakni sebesar 18\%. Hal ini menunjukkan bahwa responden belum lama menjadi akuntan dan manajer di LAZ tempat mereka bekerja.

\subsection{Hasil Uji Hipotesis}

Berdasarkan hasil uji statistik dapat dituliskan model regresi riset sebagai berikut:

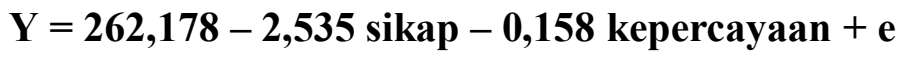

Keterangan:

1. $\mathrm{Y}=$ Minat akuntan dan manajer LAZ mengungkapkan sharia compliance, sharia governance, dan enviromental accounting.

2. Konstanta $=262,178$ (positif) dengan arah hubungan positif, artinya jika sikap dan kepercayaan akuntan dan manajer LAZ mengungkapkan sharia compliance, sharia governance, dan enviromental accounting sama dengan nol, maka niat akuntan dan manajer dalam melakukan pengungkapan kepatuhan syariah sebesar 262, 178.

3. $\mathrm{B} 1=-2,535$ (negatif) dengan arah hubungan negatif. Artinya, jika sikap akuntan dan manajer LAZ mengungkapkan sharia compliance, sharia governance, dan enviromental accounting meningkat $1 \%$, maka minat akuntan dan manajer LAZ tetap.

4. $\mathrm{B} 2=-0,158$ (negatif) dengan arah hubungan negatif. Artinya, jika kepercayaan akuntan dan manajer LAZ mengungkapkan sharia 
compliance, sharia governance, dan enviromental accounting meningkat 1 $\%$, maka minat akuntan dan manajer tetap.

\subsubsection{Koefisien Determinasi}

Berdasarkan hasil uji analisis koefisien determinasi diketahui bahwa nilai adjusted $r$ square sebesar 0,984. Artinya, bahwa variabel minat akuntan dan manajer mengungkapkan sharia compliance, sharia governance, dan enviromental accounting dipengaruhi oleh variabel sikap dan minat akuntan dan manajer sebesar $98,40 \%$ dan sisanya $1,60 \%$ dipengaruhi oleh variabel lain yang belum diteliti.

\subsubsection{Uji Simultan (Uji F)}

Berdasarkan hasil uji simultan diketahui bahwa nilai statistik uji $\mathrm{F}$ sebesar 894,383 dengan tingkat signifikansi 0,000. Artinya H1 didukung. Jadi, secara simultan variabel minat akuntan dan manajer LAZ dipengaruhi oleh sikap dan kepercayaan akuntan dan manajer LAZ dalam mengungkapkan sharia compliance, sharia governance, dan enviromental accounting.

\subsubsection{Uji Parsial (Uji t)}

Berdasarkan hasil uji parsial dihasilkan beberapa data sebagai berikut:

1. Hasil uji t $\mathrm{H} 2=-29,959$ dengan nilai signifikansi sebesar 0,000. Artinya secara parsial variabel minat akuntan dan manajer LAZ tidak dipengaruhi oleh sikap dan akuntan dan manajer LAZ dalam mengungkapkan sharia compliance, sharia governance, dan enviromental accounting.

2. Hasil uji t $\mathrm{H3}=-3,225$ dengan nilai signifikansi sebesar 0,003. Artinya secara parsial variabel minat akuntan dan manajer LAZ tidak dipengaruhi oleh kepercayaan akuntan dan manajer LAZ dalam mengungkapkan sharia compliance, sharia governance, dan enviromental accounting.

\subsection{Pembahasan}

Berdasarkan hasil uji secara simultan diketahui bahwa variabel sikap dan kepercayaan berpengaruh terhadap minat akuntan dan manajer dalam mengungkapkan sharia compliance, sharia governance, dan enviromental accounting. Riset ini sejalan dengan sharia enterprise theory dimana teori tersebut menjelaskan bahwa Allah sebagai sumber amanah yang utama. Sedangkan SDM yang dimiliki stakeholders maupun stakeholders pada prinsipnya amanah dari Allah yang di dalamnya terdapat tanggungjawab untuk menggunakannya. Riset tersebut mendukung riset yang dilakukan oleh Asrori yang melakukan riset pada bank syariah yang ada di Semarang. Hasil risetnya menunjukkan bahwa sikap dan kepercayaan dapat memengaruhi minat akuntan 
dan manajer bank syariah dalam melakukan pengungkapan kepatuhan syariah yang kemudian memengaruhi perilaku tanggungjawab akuntan dan manajer tersebut.

Berdasarkan hasil uji secara parsial diketahui bahwa sikap dan kepercayaan tidak berpengaruh terhadap minat akuntan dan manajer dalam mengungkapkan sharia compliance, sharia governance, dan enviromental accounting. Riset ini tidak sejalan dengan teori tindakan beralasan yang menyatakan bahwa sikap dan kepercayaan seseorang terhadap sesuatu pekerjaan dapat memengaruhi minat untuk melakukan pekerjaan tersebut. Hasil riset ini juga berbeda dengan riset yang dilakukan sebelumnya oleh Asrori tahun 2011. Riset yang dilakukan pada bank syariah di Semarang menunjukkan bahwa sikap dan kepercayaan secara individu berpengaruh terhadap minat akuntan dan manajer dalam mengungkapkan kepatuhan syariah.

\section{KESIMPULAN DAN SARAN}

Berdasarkan hasil riset dan pembahasan, maka kesimpulan dari riset tersebut adalah sebagai berikut:

1. Berdasarkan hasil uji statistik, secara simultan variabel sikap dan kepercayaan berpengaruh terhadap minat akuntan dan manajer dalam mengungkapkan sharia compliance, sharia governance, dan enviromental accounting.

2. Berdasarkan hasil uji statistik, secara parsial bahwa variabel sikap tidak berpengaruh terhadap minat akuntan dan manajer dalam mengungkapkan sharia compliance, sharia governance, dan enviromental accounting.

3. Berdasarkan hasil uji statistik, secara parsial bahwa variabel kepercayaan tidak berpengaruh terhadap minat akuntan dan manajer dalam mengungkapkan sharia compliance, sharia governance, dan enviromental accounting.

Keterbatasan riset tersebut adalah jumlah sampel yang relatif kecil yakni hanya 30 data pengamatan. Selain itu, riset tersebut juga tidak dapat menganalisis secara lebih detail kondisi lembaga amil zakat yang ada di Indonesia dalam melakukan pengungkapan sharia compliance, sharia governance, dan enviromental accounting dikarenakan keterbatasan peneliti dalam melakukan wawancara dengan akuntan dan manajer lembaga amil zakat tersebut.

Adapun saran dari riset tersebut antara lain: pertama, riset yang akan datang seharusnya menambah jumlah sampel yang digunakan untuk riset dan menambah variabel-variabel islami seperti perilaku tanggung jawab mengungkapkan kepatuhan syariah. Kedua, LAZ seharusnya lebih sadar dalam merumuskan kebijakan tentang pengungkapan sharia complaince, sharia governance, dan 
enviromental accounting. Ketiga, muzzaki seharusnya tidak hanya menilai indikator keuangan saja ketika hendak membayar infak, sedekah, dan wakaf di LAZ melainkan juga menilai indikator non-keuangan seperti kepatuhan LAZ terhadap prinsip syariah serta pengungkapan sosial dan lingkungan LAZ yang memiliki dampak jangka panjang. Keempat, pembuat kebijakan hendaknya dapat mengevaluasi secara berkala indikator pengungkapan islami di LAZ ataupun perusahaan organisasi nir laba lainnya.

\section{DAFTAR PUSTAKA}

AAOIFI. 2003. Accounting, Auditing and Governan Standards for Islamic Financial Institutions.Accounting and Auditing Organization for Islamic Financial Institution. Manama, Bahrain.

Alquran dan Terjemahannya: Departemen Agama.

Asrori, 2011. Pengungkapan Syariah Compliance dan kepatuhan bank syariah terhadap prinsip syariah. Jurnal Dinamika Akuntansi Vol. 3 no.1. Unnes: ISSN 2085-4277.

Baydoun dan Willet. 2000. Islamic Corporate Reports. ABACUS, Vol. 36 No. 1, 71- 90 .

Bassam, M., P. Casson dan C. Napier. 2006. Social Reporting by Islamic Banks. ABACUS, Vol. 42 No. 2, 266-289.

Gefen, D., Rigdon, E.E., and Straub, D. 2011. "An Update and Extension to SEM Guidelines for Administrative and Social Science Research," MIS Quarterly (35:2), pp.iii-xiv.

Ghazali dan Hengky. 2012. Partial Least Square Konsep Metode dan Aplikasi.Semarang: Badan Penerbit Universitas Diponegoro.

Hameed, S. et al. 2003. Alternatif Disclosure and Performance Measures for Islamic Banks. Paper Presented in the Internastional Conference on Information System and Islam at the IIUM. Kuala Lumpur. hal. 1-34.

Hameed, S. dan Y. Rizal. 2003. ! e Future of Islamic Corporate Reporting: Lessons from Alternative Western Accounting Report. Paper Presented in the Internastional Conference on Quality Financial Reporting and Corporate Gavernance. Kuala Lumpur. 28-28 July 2003.

Hasan, Zulkifli. 2011. A survey on Shari'ah governance practices in Malaysia, GCC countries and the UK Critical appraisal. International Journal of Islamic and Middle Eastern Finance and Management Vol. 4 No. 1, 2011 pp. 30-51. Emerald Group Publishing Limited 1753-8394. 
Hamza, Hichem. 2012. Sharia governance in Islamic banks: effectiveness and supervision model. International Journal of Islamic and Middle Eastern Finance and Management Vol. 6 No. 3, 2013 pp. 226-237. Emerald Group Publishing Limited 1753-8394.

Kuncoro, Mudrajad. 2009. Metode Riset untuk Bisnis dan Ekonomi. Edisi 3. Jakarta : Penerbit Erlangga.

Mathews, M.R. (1997), Twenty-Five Years Of Social And Environmental Accounting Research: Is There A Silver Jubilee To Celebrate?, Accounting, Auditing \& Accountability Journal, Vol. 10, No. 4, pp481-531.

Peraturan Bank Indonesia nomor 11 Th. 2009. tentang Unit Usaha Syariah.

Peraturan Bank Indonesia nomor 13 Th. 2011. tentang Penerapan Manajemen Risiko bagi Bank Umum syariah dan Unit Usaha Syariah.

Peraturan Bank Indonesia nomor 14 Th. 2012. Tentang Uji Kemampuan dan Kepatuhan (Fit and Proper Test) Bank Umum Syariah dan Unit Usaha Syariah.

Rezaee, Zabihollah. 2006. Corporate Governance Post-Sarbanes-Oxley. Regulations, Requirements, and Integrated Processes. USA:Mempis.

Pirouz, D. M. 2006. "An Overview of Partial Least Square," The Paul Merage School of business university of California, Irvine pp.1-16. Sarwono, Jonathan. 2012. Metode Riset Skripsi Pendekatan Kuantitatif Menggunakan Prosedur SPSS. Jakarta: Gramedia Pustaka.

Tobias, R.D. 1997. An Introduction to Partial Least Squares Regression. SAS Institute, Inc., Cari, NC. pp 1-8.

Triyuwono, Iwan. 2006. Perspektif, Metodologi, dan Teori Akuntansi Syariah. PT Raja Grafindo: Jakarta. 